\section{Case Reports in Gastroenterology}

Case Rep Gastroenterol 2017;11:680-685

DOI: $10.1159 / 000484131$

Publisned onine: November 9, 2017 (c) 2017 The Author(s)

Published by S. Karger AG, Basel www.karger.com/crg

This article is licensed under the Creative Commons Attribution-NonCommercial 4.0 International License (CC BY-NC) (http://www.karger.com/Services/OpenAccessLicense). Usage and distribution for commercial purposes requires written permission.

\title{
Autoimmune Hepatitis: A Risk Factor for Cholangiocarcinoma
}

\author{
Rajat Garg ${ }^{a} \quad$ Uqba Khan $^{\mathrm{b}} \quad$ Ahmed AlRajjal $^{c} \quad$ Zyad Kafrib \\ ${ }^{a}$ Department of Internal Medicine, St. John Hospital and Medical Center, Detroit, MI, USA; \\ ${ }^{b}$ Division of Hematology and Oncology, St. John Hospital and Medical Center, \\ Detroit, MI, USA; ' Department of Pathology and Laboratory Medicine, St. John Hospital \\ and Medical Center, Detroit, MI, USA
}

\section{Keywords}

Cholangiocarcinoma $\cdot$ Autoimmune hepatitis $\cdot$ Hepatitis $\cdot$ Risk factors

\begin{abstract}
Cholangiocarcinoma (CCA) is a very aggressive and lethal tumor, which arises from the epithelial cells of bile ducts. CCA comprises about $3 \%$ of all gastrointestinal malignancies and its incidence is on the rise in the recent years. Anatomically, it is classified into intrahepatic, perihilar, or extrahepatic (distal) CCA. There are a number of risk factors associated with CCA including primary sclerosing cholangitis, fibropolycystic liver disease, parasitic infection, viral hepatitis, chronic liver disease, and genetic disorders like Lynch syndrome. Autoimmune hepatitis is also recently reported to have an association with development of CCA. We report an interesting case of perihilar CCA in the setting of autoimmune hepatitis along with a literature review. This case highlights the importance of early treatment and close clinical followup of patients with autoimmune hepatitis for development of CCA.
\end{abstract}




\section{Case Reports in Gastroenterology}

Case Rep Gastroenterol 2017;11:680-685

DOI: 10.1159/000484131

(C) 2017 The Author(s). Published by S. Karger AG, Basel www.karger.com/crg

Garg et al.: Autoimmune Hepatitis: A Risk Factor for Cholangiocarcinoma

\section{Introduction}

Cholangiocarcinoma (CCA) is a biliary tumor arising from epithelial cells of bile ducts and can be classified depending on the location of the tumor in biliary tract. It can be classified as intrahepatic located proximal to second-degree bile ducts, perihilar located between second-degree bile ducts to cystic duct insertion, and distal CCA, distal to cystic duct insertion. Most common location is perihilar (50\%) followed by distal (40\%) and intrahepatic (10\%) [1]. Incidence of cholangiocarcinoma is rising in recent years. There are multiple risk factors associated with development of CCA including primary sclerosing cholangitis, fibropolycystic liver disease, parasitic infection, viral hepatitis, chronic liver disease, and genetic disorders like Lynch syndrome. We here report an interesting case of CCA developed in the setting of autoimmune hepatitis $(\mathrm{AIH})$ along with a review of literature and postulate a possible association of CCA with AIH.

\section{Case Report}

A 57-year-old African-American male was diagnosed with AIH 5 years ago. At his initial presentation, he was incidentally found to have leukopenia, thrombocytopenia, and elevated liver enzymes. The patient then underwent comprehensive laboratory and radiological workup to determine the underlying etiology. His initial laboratory investigation revealed WBC of $3,000 / \mathrm{mm}^{3}$, hemoglobin of $15.2 \mathrm{~g} / \mathrm{dL}$, platelets of $97,000 / \mathrm{mm}^{3}$, creatinine of 0.97 $\mathrm{mg} / \mathrm{dL}, \mathrm{AST}$ of 123 units/L, ALT of 83 units/L, alkaline phosphatase of 457 units/L, bilirubin of $1 \mathrm{mg} / \mathrm{dL}$, albumin of $4.4 \mathrm{~g} / \mathrm{dL}$, and prothrombin time of $15 \mathrm{~s}$. Viral hepatitis profile for $\mathrm{A}$, $\mathrm{B}$, and $\mathrm{C}$ was negative. Serology for ANA, c-ANCA, ds-DNA, liver-kidney microsome IgG, proteinase 3 antibody, myeloperoxidase antibody, smooth muscle antibody, and HIV were negative. P-ANCA and single-stranded DNA were positive. Serum electrophoresis showed elevated IgG level of 2,970 mg/dL (reference range: 751-1,560). He also underwent bone marrow biopsy due to leukopenia and thrombocytopenia, which revealed no evidence of lymphoproliferative disorder. CT scan of abdomen revealed hepatosplenomegaly. He also underwent liver biopsy, which showed active hepatitis with sinusoidal T-cell infiltrates (Fig. 1, Fig. 2). Patient clinical presentation was secondary to possible AIH (according to Revised Original Scoring System of the International Autoimmune Hepatitis Group). He was initially treated with high-dose steroids without clinical or biochemical improvement. He was then observed clinically with frequent monitoring of his liver function tests. His medical history was significant for hypertension and chronic pancreatitis. He was not taking any routinely prescribed medications. He had a prior history of smoking as well as alcoholism. Family history was significant for acute leukemia in the father and brother.

After approximately 5 years of close clinical follow-up, the patient presented with generalized abdominal pain and worsening liver enzymes. His bilirubin increased from 0.9 $\mathrm{mg} / \mathrm{dL}$ to $4.5 \mathrm{mg} / \mathrm{dL}$, alkaline phosphatase increased to 1,098 U/L from baseline of $400 \mathrm{U} / \mathrm{L}$ with liver transaminase staying close to his baseline of 100-150 U/L. The patient underwent magnetic resonance cholangiopancreatography (MRCP), which revealed intrahepatic biliary dilatation and stricture at the porta hepatis. Endoscopic retrograde cholangiopancreatography (ERCP) revealed a $2-\mathrm{cm}$ stricture in the common bile duct extending into the right 


\section{Case Reports in \\ Gastroenterology}

Case Rep Gastroenterol 2017;11:680-685

DOI: 10.1159/000484131

(C) 2017 The Author(s). Published by S. Karger AG, Basel www.karger.com/crg

Garg et al.: Autoimmune Hepatitis: A Risk Factor for Cholangiocarcinoma

intrahepatic biliary tree. Biopsy confirmed the diagnosis of cholangiocarcinoma (Fig. 3). CT scan of chest, abdomen, and pelvis revealed no distant metastasis. The patient was evaluated by the liver transplant team but was deemed unqualified for liver transplant due to recurrent cholangitis at the time of initial evaluation. The patient was not a surgical candidate due to his extensive underlying liver disease. The patient was then started on systemic chemotherapy with gemcitabine and cisplatin. He successfully completed 6 cycles of treatment. PET scan after 6 cycles of treatment showed no evidence of malignancy. The patient is currently being followed by the transplant team for possible liver transplant in the future.

\section{Discussion}

According to National Cancer Institute data, the incidence of CCA is on the rise. It represents $2.3 \%$ of new cancer cases in the US and affects 8.4 per 100,000 men and women per year based on 2009-2013 data [2]. CCA is a devastating malignancy with a dismal 5-year survival rate of only $17.5 \%$. Identifying potential risk factors of CCA will help in early recognition potentially affecting patient outcomes. Classic risk factors associated with CCA are choledochal cysts, cholangitis, inflammatory bowel disease, cirrhosis, diabetes, thyrotoxicosis, and chronic pancreatitis [3]. Several other risk factors associated with intrahepatic CCA are hepatitis $C$ infection, cirrhosis, human immunodeficiency, and diabetes [3, 4]. AIH has been associated most commonly with hepatocellular carcinoma with few reported cases of gastric, colon, and cervical cancer [5]. CCA is a rare manifestation of AIH and only 4 other cases have been reported in the English literature. AIH has been proposed to be one of the rare risk factors for the CCA.

Our patient was incidentally found to have elevated liver enzymes and subsequently, liver biopsy showed T-cell infiltration and hepatitis without any associated necrosis. His viral serology was negative and so were antinuclear antibody, anti-smooth muscle antibody, antimitochondrial antibody, and anti-liver-kidney microsome. This led to a diagnosis of Tcell-mediated liver injury secondary to AIH. On careful literature review, only 4 cases of CCA associated with AIH have been reported in the literature and are summarized in Table 1 [58]. In the first case described in 2008, there was a long interval of 30 years in the development of CCA after diagnosis of AIH. There was presence of cirrhosis in one case and another patient had grade 4 fibrosis on pathology, which also might have contributed to the development of CCA.

Primary sclerosing cholangitis (PSC) is considered the most common predisposing factor for CCA, while fluke infections show the strongest relation to CCA in the Far East [9]. Both PSC and infection create a chronic inflammatory environment within the biliary tree for an extended period of time. The activated immune system contributes to a variety of growth factors, cytokines, and tyrosine kinases, which leads to alterations in the surrounding tissue ranging from proliferation and cell-cycle dysregulation to apoptosis [10]. Cytokines will induce nitric oxide synthase, producing excessive amount of nitric oxide, a free radical, which results in damage to the DNA and DNA repair enzymes [11]. Interleukin-6 (IL-6) is an inflammatory cytokine with mitogenic properties $[12,13]$. It induces myeloid cell leukemia (MCL-1), an anti-apoptotic protein that acts by inducing tumor necrosis factor resistance to its activating ligand. Studies have shown that IL-6 induces MCL-1 expression and is pro- 
Garg et al.: Autoimmune Hepatitis: A Risk Factor for Cholangiocarcinoma

duced by the malignant cells in CCA. IL- 6 serum level is elevated in CCA patients. The signaling pathway during prolonged inflammation promotes DNA damage and blocks apoptosis eventually leading to malignant transformation.

In case of $\mathrm{AIH}$, an immune reaction against liver antigens mediated by lymphocytes, macrophages, and plasma cells forms a similar inflammatory environment to CCA. Also, a recent study has shown that the intricate inflammatory process in AIH patients results in elevated serum IL-6 level [14]. The chronic inflammation and the elevated IL-6 serum levels support our hypothesis of AIH as a risk factor leading to cholangiocarcinoma. Some authors have suggested regular surveillance with CA 19-9 and ultrasound abdomen in patients with AIH to diagnose CCA at any early stage [6]. The detection of CCA at early stage leads to improvement in prognosis and survival.

Our case again highlights the rare association of CCA and AIH and is the 5th case reported in the literature. It also highlights the importance of early treatment and close clinical monitoring of every patient of AIH for development of CCA.

\section{Statement of Ethics}

Written informed consent was obtained from the patient for publication of this case report and any accompanying images.

\section{Disclosure Statement}

All authors disclose that there are no potential conflicts (financial, professional, or personal) that are relevant to the manuscript.

\section{References}

1 Razumilava N, Gores GJ: Cholangiocarcinoma. Lancet 2014;383:2168-2179.

2 SEER Cancer Stat Facts: Liver and Intrahepatic Bile Duct Cancer. National Cancer Institute, Bethesda, http://seer.cancer.gov/statfacts/html/livibd.html.

-3 Welzel TM, Graubard BI, El-Serag HB, Shaib YH, Hsing AW, Davila JA, et al: Risk factors for intrahepatic and extrahepatic cholangiocarcinoma in the United States: a population-based case-control study. Clin Gastroenterol Hepatol 2007;5:1221-1228.

4 Shaib YH, El-Serag HB, Davila JA, Morgan R, McGlynn KA: Risk factors of intrahepatic cholangiocarcinoma in the United States: a case-control study. Gastroenterology 2005;128:620-626.

-5 Izumi S, Nakamura S, Mano S: Large intrahepatic cholangiocarcinoma with tumor infiltrative lymphocytes and autoimmune hepatitis-like features. Case Rep Gastroenterol 2010;4:46-51.

6 Elfaki DH, Gossard AA, Lindor KD: Cholangiocarcinoma: expanding the spectrum of risk factors. J Gastrointest Cancer 2008;39:114-117.

7 Rial NS, Henderson JT, Bhattacharyya AK, Nadir A, Cunningham JT: Use of endoscopic ultrasound for diagnosis of cholangiocarcinoma in auto-immune hepatitis. World J Gastrointest Endosc 2010;2:404407.

8 Yoshizawa K, Matsumoto A, Ichijo T, Umemura T, Joshita S, Komatsu M, et al: Long-term outcome of Japanese patients with type 1 autoimmune hepatitis. Hepatology 2012;56:668-676.

9 Chapman RW: Risk factors for biliary tract carcinogenesis. Ann Oncol 1999;10(suppl 4):308-311. 


\section{Case Reports in Gastroenterology}

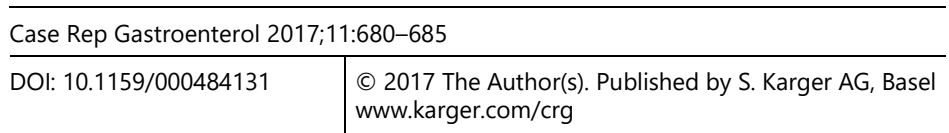

Garg et al.: Autoimmune Hepatitis: A Risk Factor for Cholangiocarcinoma

10 Blechacz B, Gores GJ: Cholangiocarcinoma: advances in pathogenesis, diagnosis, and treatment. Hepatology 2008;48:308-321.

11 Ahrendt SA, Rashid A, Chow JT, Eisenberger CF, Pitt HA, Sidransky D: p53 overexpression and K-ras gene mutations in primary sclerosing cholangitis-associated biliary tract cancer. J Hepatobiliary Pancreat Surg 2000;7:426-431.

12 Watanabe M, Asaka M, Tanaka J, Kurosawa M, Kasai M, Miyazaki T: Point mutation of K-ras gene codon 12 in biliary tract tumors. Gastroenterology 1994;107:1147-1153.

13 Isa T, Tomita S, Nakachi A, Miyazato H, Shimoji H, Kusano T, et al: Analysis of microsatellite instability, K-ras gene mutation and p53 protein overexpression in intrahepatic cholangiocarcinoma. Hepatogastroenterology 2002;49:604-608.

14 Zhao L, Tang Y, You Z, Wang Q, Liang S, Han X, et al: Interleukin-17 contributes to the pathogenesis of autoimmune hepatitis through inducing hepatic interleukin-6 expression. PLoS One 2011;6:e18909.

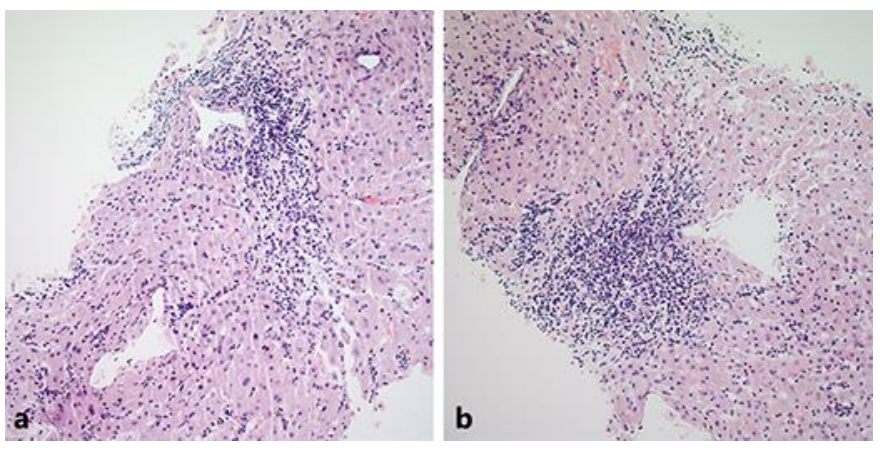

Fig. 1. a, b Hematoxylin and eosin (H\&E) stain of liver biopsy showing sinusoidal lymphocytic infiltrate (20× magnification).
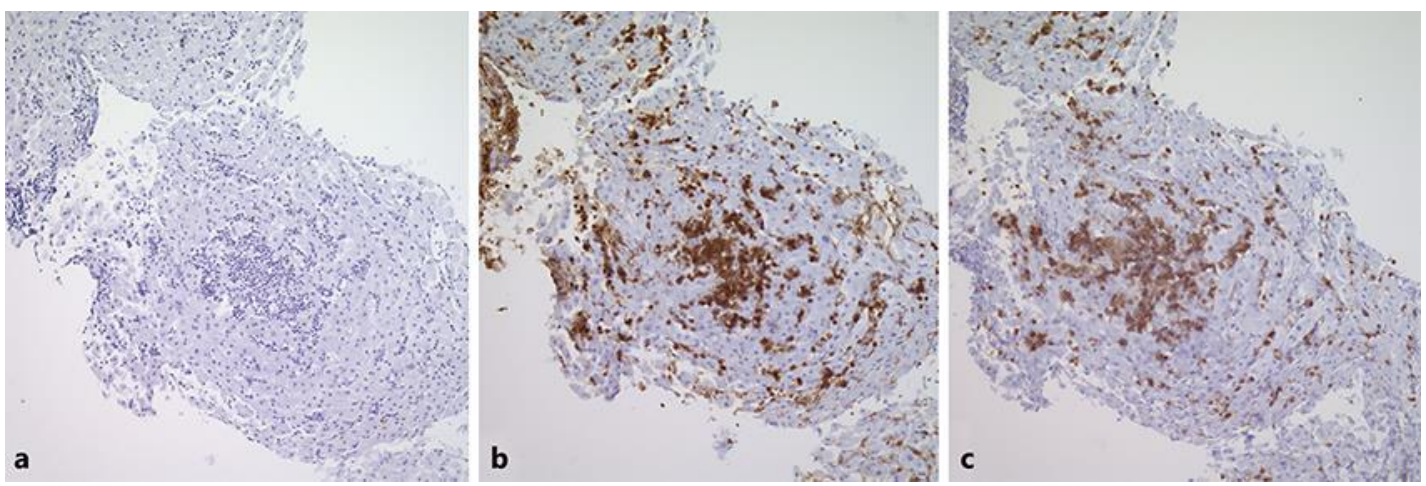

Fig. 2. CD20 immunohistochemically staining the infiltrative area showing negative staining (a), CD3 immunohistochemically stained section highlighting the sinusoidal infiltrate of T cells (b), and CD5 immunohistochemically stained section confirming the T-cell nature of this infiltrate (c) ( $4 \times$ magnification). 

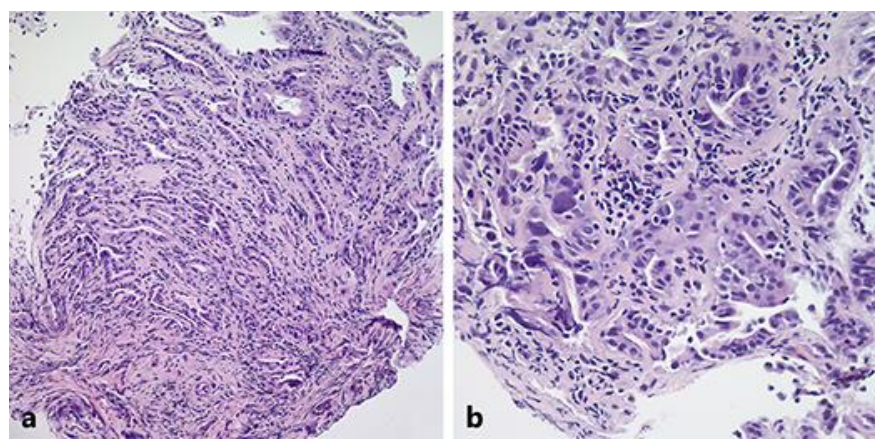

Fig. 3. 20 $\times$ H\&E-stained sections of the common bile duct showing the invasive nature of the adenocarcinoma (a). 40× H\&E staining of the same section demonstrating irregular glands, cellular atypia, and nuclear pleomorphism (b).

Table 1. Reported cases of cholangiocarcinoma (CCA) associated with autoimmune hepatitis (AIH)

\begin{tabular}{|c|c|c|c|c|c|c|c|c|c|}
\hline Author & Year & $\begin{array}{l}\text { Age, } \\
\text { years }\end{array}$ & Sex & Serology & CCA type & $\begin{array}{l}\text { CA-19 } \\
\text { level }\end{array}$ & $\begin{array}{l}\text { Time since } \\
\text { diagnosis } \\
\text { of AIH }\end{array}$ & $\begin{array}{l}\text { Presence of } \\
\text { cirrhosis at time of } \\
\text { diagnosis }\end{array}$ & $\begin{array}{l}\text { Follow-up } \\
\text { since CCA } \\
\text { diagnosis }\end{array}$ \\
\hline Elfaki et al. [6] & 2008 & 55 & $\mathrm{~F}$ & NA & Intrahepatic & 163 & 30 years & Possible cirrhosis & 7 months \\
\hline Rial et al. [7] & 2010 & 64 & $\mathrm{~F}$ & $\begin{array}{l}\text { ANA +, } \\
\text { AMA +, } \\
\text { ASMA - }\end{array}$ & Distal & NA & NA & Positive & NA \\
\hline Izumi et al. [5] & 2010 & 81 & M & Negative & Intrahepatic & 99 & Acute & Negative & 28 months \\
\hline Yoshizawa et al. [8] & 2012 & 60 & $\mathrm{~F}$ & NA & NA & NA & 17 years & Negative & NA \\
\hline Our case & 2017 & 57 & M & $\begin{array}{l}\text { ANA -, } \\
\text { ASMA -, } \\
\text { AMA - }\end{array}$ & Perihilar & 2.5 & 5 years & Negative & $\begin{array}{l}1 \text { year till } \\
\text { present }\end{array}$ \\
\hline
\end{tabular}

NA, not available. ANA, antinuclear antibody; ASMA, anti-smooth muscle antibody; AMA, antimitochondrial antibody; -, negative; +, present. 